\title{
Influence of Diceraeus melacanthus (Hemiptera:Pentatomidae) on the Development and Reactive-Oxigen-Related Enzyme Activity of Corn Seedlings
}

\author{
T. M. Pascutti ${ }^{1}$, É. M. P. Coelho ${ }^{1}$, E. P. Prado ${ }^{2}$, P. J. Ferreira Filho ${ }^{3}$, A. L. Boiça Junior ${ }^{4} \&$ J. C. Guerreiro ${ }^{1}$ \\ ${ }^{1}$ Departamento de Ciências Agronômicas, Universidade Estadual de Maringá, Umuarama, Brazil \\ ${ }^{2}$ Faculdade de Ciências Agrárias e Tecnológicas, Universidade Estadual Paulista "Júlio de Mesquita Filho", \\ Dracena, Brazil \\ ${ }^{3}$ Departamento de Ciências Ambientais, Universidade Federal de São Carlos, Sorocaba, Brazil \\ ${ }^{4}$ Departamento de Ciências da Produção Agrícola, Faculdade de Ciências Agrárias e Veterinárias, Universidade \\ Estadual Paulista "Júlio de Mesquita Filho", Jaboticabal, Brazil \\ Correspondence: Thaise Mylena Pascutti, Departamento de Ciências Agronômicas, Universidade Estadual de \\ Maringá, Estrada da Paca s/n, CEP: 87500-000, Bairro São Cristovão, Umuarama, PR, Brazil. E-mail: \\ thaypascutti@hotmail.com
}

Received: December 28, 2020

Accepted: February 16, $2021 \quad$ Online Published: March 15, 2021

doi:10.5539/jas.v13n4p43

URL: https://doi.org/10.5539/jas.v13n4p43

The research is financed by CAPES.

\begin{abstract}
The damage caused by insect pests in plants can considerably affect their development and crop yield. It can also cause the activation of biochemical defense mechanisms in the plant, combined with the production of reactive oxygen species. The levels of these oxygen molecules are controlled by antioxidant enzymes and this mechanism is an important plant defense process. The aim of this study is to learn the effect of feeding by the stink bug, Diceraeus melacanthus, on the growth of corn plants and on the activity of the antioxidant enzyme peroxidase (POD) and catalase (CAT). The study was carried out in a greenhouse, in a completely randomized design, with a $2 \times 4$ factorial block and five replications. The first factor was composed of plants with and without the presence of the bug and the second factor was composed the age of corn plants, two, four, six, and eight days after emergence. Corn seedlings infested with the stink bug were negatively influenced in terms of plant height, root mass and increasing in activity of the POD enzyme was $84 \%$ higher in plants infested at $8^{\text {th }}$ DAE. The CAT enzyme activity was not detected in the samples. The stink bug feeding affected the growth of the corn seedlings. The analysis of the POD enzyme could be a valuable tool to quantify the stress caused by the stink bug in futures studies.
\end{abstract}

Keywords: green belly stink bug, corn pests, injuries, antioxidant enzymes, peroxidase and catalase

\section{Introduction}

The corn plant Zea mays L. (Poaceae) can be affected by several pests that attack from the root, to the stalk and leaves, to the corn cob, causing damage throughout the cultivation cycle, if not properly managed. Among the pests, the green belly stink bugs species Diceraeus melacanthus Dallas, 1851 and Diceraeus furcatus Fabricius, 1775 (Heteroptera: Pentatomidae) are causing significant damage to the crop (Fernandes et al., 2020).

The stink bugs of the genus Diceraeus spp. (Hemiptera: Pentatomidae) gained prominence in the main producing regions, during the planting period of the second harvest. The dynamics of cultivation, such as, the anticipation of the soybean harvest and the consequent planting of corn in mid-January and February, coincide with the peak period of the stink bugs, which may culminate in significant damage to the crops (Chocorosqui \& Panizzi, 2004). The greater occurrence of this pest is also related to the systematic adoption of the succession of soybean crops by corn crops and to the 'no-tillage system', which promotes favorable conditions for the development of phytophagous insects. So far, there exist a few control strategies that work efficiently (Chiesa et al., 2016). 
The species D. melacanthus has a predominant occurrence in Brazil. Its presence in crops is related to its more active behavior in hot regions, with subtropical and tropical climate conditions, where the main agricultural areas of corn cultivation in the country are located (Chocorosqui, 2001). This insect feeds on cellular compounds of the plant's parenchymal tissue and xylem vessels (Lucini \& Panizzi, 2018), preferring the base of the corn seedling stem as the main feeding point (Panizzi \& Lucini, 2019). The potential for injuries caused by this stink bug can be particularly observed from nymphs of the fourth and fifth instar to adults, developmental stages that are responsible for causing significant damage to corn (Fernandes et al., 2020).

The injuries caused by D. melacanthus can vary from small perforations in the leaves, the induction of the tillering of the plant, injuries and withering of the leaves, and even more severe damage such as destruction of the apical meristem that can kill the plant. The attack of this stink bug affects the development of the plant, and makes it less vigorous, resulting in a reduced plant height and number of developed leaves. This impact can compromise the root system and normal development of the plant, resulting in negative results in grain productivity (Roza-Gomez et al., 2011; Crosariol Netto et al., 2015; Bridi et al., 2016).

Besides affecting the development of the plant, the stink bug feeding can induce the activation of defense mechanisms (Bi \& Felton, 1995). One of the mechanisms triggered by plants is the production of defensive biochemical compounds in response to the herbivorous activity. Among these compounds are the reactive oxygen species (ROS) (Inzé \& Montagu, 1995; War et al., 2012).

The most common ROS in plants are hydrogen peroxide $\left(\mathrm{H}_{2} \mathrm{O}_{2}\right)$, hydroxyl radical $\left(\mathrm{OH}^{-}\right)$and the superoxide anion $\left(\mathrm{O}_{2}^{-}\right)$. These molecules are accumulated in parts of plants during the period of stress suffered by the induction of some agent, however, they are toxic both to the stressor and to the plants themselves. Consequently, the plant uses mechanisms to produce a complex of antioxidant enzymes that are able to fight and decompose the formed ROS, so that the plant can return to its normal biochemical state. The main antioxidant enzymes produced by plants that aid in the degradation process of ROS are, superoxide dismutase, peroxidase, glutathione reductase, catalase, and polyphenol oxidase (Maffei et al., 2007; Soares \& Machado, 2007; Nascimento \& Barrigossi, 2014).

Hydrogen peroxide $\left(\mathrm{H}_{2} \mathrm{O}_{2}\right)$ is one of the main ROS formed by the plant and is closely linked to the plant's defense process. It can be considered as a type of response to stress caused by insect pest damage (Soares \& Machado, 2007). The degradation of this ROS is a major function of the enzymes catalase and peroxidase, so to study the enzyme activity is very interesting after insects feeding. It is suggested, then, that the expression of these specific enzymes is a part response and strategy of induced resistance caused by insect feeding (Nascimento \& Barrigossi, 2014).

According to the content explained, the study aimed to learn the effect of the presence of D. melacanthus on the development of corn plants and on the activity of the antioxidant enzymes catalase and peroxidase.

\section{Material and Methods}

The experiment was carried out in a greenhouse and in the Entomology and Biochemistry Laboratories at the State University of Maringá (UEM), Umuarama Campus, PR, Brazil in November 2017.

First-generation adult stink bugs reared in the laboratory were used to carry out the tests. The breeding was initialized with adult stink bugs captured in the field on host plants and kept in the Entomology laboratory under controlled conditions of temperature $\left(25 \pm 2{ }^{\circ} \mathrm{C}\right)$, relative humidty $(65 \pm 10 \%)$ and a photoperiod of 12 hours.

The insects were kept in transparent plastic boxes $(40.8 \mathrm{~cm} \times 29.0 \mathrm{~cm} \times 12.6 \mathrm{~cm})$ with perforations for gas exchange. The rearing box was lined with filter paper that remained moist throughout the period. Cotton was also deposited into the boxes to serve as oviposition sites for stink bugs, which were fed with a natural diet, composed of fresh bean pods (Phaseolus vulgaris L., Fabaceae), tree privet fruit (Ligustrum lucidum W. T. Aiton, Oleraceae.), dried soybeans (Glycine max L. Merril, Fabaceae) and corn seedlings (Z. mays), according to methodology adapted from Chocorosqui and Panizzi (2002).

The experiment was carried out under greenhouse conditions in a completely randomized design with eight treatments, divided into a $2 \times 4$ factorial scheme and five replications. The first factor consisted of plants with and without the presence of the bug. The second factor was represented by the age of the corn plants and the consequent period of coexistence between pests and plants, corresponding to 2, 4, 6, and 8 days after emergence (DAE).

The experimental unit consisted of a polyethylene bag with capacity of $5 \mathrm{dm}^{3}$ of soil, where just one corn plant of the conventional hybrid Pioneer ${ }^{\circledR}$ 30F53 was grown. One adult stink bug non-sexed with 15 old day was artificially infested in each plant, the infestation occurred immediately after the emergence of the corn seedlings. 
All plants in the experimental units (including those that were not available for the consumption of $D$. melacanthus) were surrounded by cloth "voile", attached by rubber band around the polyethylene bag, forming a study arena, not possibility entry and exit of others insects. Before infestation, all stink bugs were kept without food for a period of 12 hours.

The agronomically relevant attributes, such as plant height, root length, dry mass of aerial part (DMAP), dry root weight (RDM), and the activity of antioxidant enzymes peroxidase (POD) and catalase (CAT) were evaluated on the respective days of development of plants $(2,4,6$, and 8 DAE), both in the treatments with and without presence of bugs, following were be evaluations of destruction in the plants. The datas were collected until $8^{\text {th }}$ DAE, the most susceptible phase of the crop to attack by the stink bug.

To quantify the activity of CAT and POD enzymes, parts of the basal leaves and stems of the seedlings, about 0.5 $\mathrm{g}$, were used, which were homogenized in a previously cooled mortar $\left(4 \pm 2{ }^{\circ} \mathrm{C}\right)$ with $5.0 \mathrm{ml}$ of potassium phosphate buffer extraction medium $[67 \mathrm{mM}], \mathrm{pH}=7.0$, and $0.1 \mathrm{~g}$ of $1 \% \mathrm{PVP}(\mathrm{w} / \mathrm{v})$ (polyvinylpyrrolidone). The homogenate was centrifuged at $3000 \mathrm{rpm}$ for 10 minutes in room temperature and the supernatant was used as an enzyme extract.

The POD was quantified with an aliquot of $500 \mu \mathrm{l}$ of the plant extract that was added to $3 \mathrm{ml}$ of the reaction medium consisting of $25 \mathrm{mM}$ potassium phosphate buffer, $\mathrm{pH}=6.8,50 \mu \mathrm{l}$ of $\mathrm{H}_{2} \mathrm{O}_{2}(10 \mathrm{mM})$, and $100 \mu \mathrm{l}$ of guaiacol $(2.58 \mathrm{mM})$. The POD activity was read using spectrophotometer at a wavelength of $470 \mathrm{~nm}$, and the increase in absorbance was measured using the extinction coefficient of $25.5 \mathrm{mM}^{-1} \mathrm{~cm}^{-1}$ (Pütter, 1974). The result was expressed in nmol of tetraguaiacol produced $\min ^{-1} \mathrm{mg}$ protein ${ }^{-1}$.

For CAT, a $100 \mu \mathrm{l}$ aliquot of the plant extract was added to $3 \mathrm{ml}$ of the reaction medium, consisting of $25 \mathrm{mM}$ potassium phosphate buffer, $\mathrm{pH}=7.0$, and $50 \mu \mathrm{l}$ of $\mathrm{H}_{2} \mathrm{O}_{2}(10 \mathrm{mM})$. The CAT activity was read using spectrophotometer at a wavelength of $290 \mathrm{~nm}$, and measured by decrease of absorbance using the extinction coefficient of $0.0394 \mathrm{mM}^{-1} \mathrm{~cm}^{-1}$ (Aebi, 1984). The result was expressed in nmol of $\mathrm{H}_{2} \mathrm{O}_{2}$ consumed at $\mathrm{min}^{-1} \mathrm{mg}$ protein $^{-1}$.

The data obtained from plant height (HT), root length, DMAP, RDM, and POD enzyme activity were submitted for analysis to check the homogeneity of the variances by the Brow Forsythe test, and normality by the Kolmogorov-Smirnov test. Having met these requirements, the data were subjected to analysis of variance (ANOVA) using the $\mathrm{F}$ test and the means were compared using the Tukey test $(P \leq 0.05)$, and when necessary, the data were transformed into $\log (\mathrm{X})$. For statistical analysis, the SAS 9.4 software was used (Sas Institute, 2013).

\section{Results}

There was a significant difference in the plant age factor in all variables analyzed $(P \leq 0.05)$. The influence of the insect factor, characterized by the presence or absence of the stink bug, D. melacanthus, was observed for plant height, RDM, and POD enzyme activity. In the interaction between the factors of plant age and insects, significant differences were observed only for the enzyme POD $(F=8.94 ; P \leq 0.05)$ (Table 1).

Table 1. Two-way ANOVA summary for the variables analyzed: plant height (HT), root length (RL), dry mass of aerial part of plants (DMAP), root dry mass (RDM), and peroxidase enzyme (POD)

\begin{tabular}{llllll}
\hline \multirow{2}{*}{ Variation } & \multicolumn{5}{c}{ Calculated $F$ value } \\
\cline { 2 - 5 } & HT & RL & DMAP & ${ }^{1}$ RDM & ${ }^{1}$ POD \\
\hline Age (A) & $12.38^{*}$ & $7.07^{*}$ & $40.81^{*}$ & $56.07^{*}$ & $5.42^{*}$ \\
Insect (I) & $25.81^{*}$ & $3.11^{\mathrm{ns}}$ & $0.00^{\mathrm{ns}}$ & $5.43^{*}$ & $60.02^{*}$ \\
$(\mathrm{~A} \times \mathrm{I})$ & $1.23^{\mathrm{ns}}$ & $0.49^{\mathrm{ns}}$ & $1.15^{\mathrm{ns}}$ & $2.00^{\mathrm{ns}}$ & $8.94^{*}$ \\
\hline C.V. $(\%)$ & 14.33 & 27.02 & $22.33^{-}$ & 14.59 & 45.95 \\
\hline
\end{tabular}

Note. ${ }^{*}{ }^{\text {ns: }}$ : Significant at $5 \%$ probability and not significant, respectively.

${ }^{1}$ Data transformed into Log X.

C.V. (\%): Coefficient of variation.

The heights of the corn plants were influenced by the insect factor, due to the presence or absence of the stink bug $D$. melacanthus, and by the age of the plants (Table 2). A reduction in the growth of the plants was attributed to the presence of bugs compared to plants without bugs. Insect-infested plants showed decreased growth and 
development from the second DAE, with an average reduction of $23.5 \%$. This pattern of impaired plant growth was observed until the eighth day after emergence of corn seedlings, with an average reduction of $26.8 \%$.

No significant difference was observed for root growth and DMAP in all evaluations. These parameters were similar affected in plants with and without stink bug infestation.

When the RDM was evaluated at $2^{\text {nd }} \mathrm{DAE}$, it was observed that there was no significant difference in the root mass between the roots with the presence or absence of the pest. This short period of bug-plant coexistence was not enough for the manifestation of changes in plant structure, however, the root mass of the plants was negatively altered at 4 and 6 DAE. It was noted that with a longer period of coexistence of the pest and plant, there were significant losses of mass of the root system. In implying a decrease in the RDM. In relative terms, the decrease in root mass was $55 \%$ and $67 \%$, at $4^{\text {th }}$ and $6^{\text {th }}$ DAE, respectively. However, on $8^{\text {th }}$ DAE, there was observed a recovery of the root mass in contrast to the decrease in dimension and mass of aerial plant parts.

The presence of D. melacanthus resulted in a constant increase in POD activity according to the time after infestation. Differences in POD concentration there was not occurred 2th DAE, probably due to the short time of establishment of bugs in plant populations, implying little impact in this period, and consequently low plant response to the presence of the stink bug. On $8^{\text {th }}$ DAE, the plants infested with the bug showed $84 \%$ higher POD activity, when compared to plants kept without the insect, inferring the oxidative stress state of the plants, in response to the injury caused by the pest (Table 2 and Figure1).

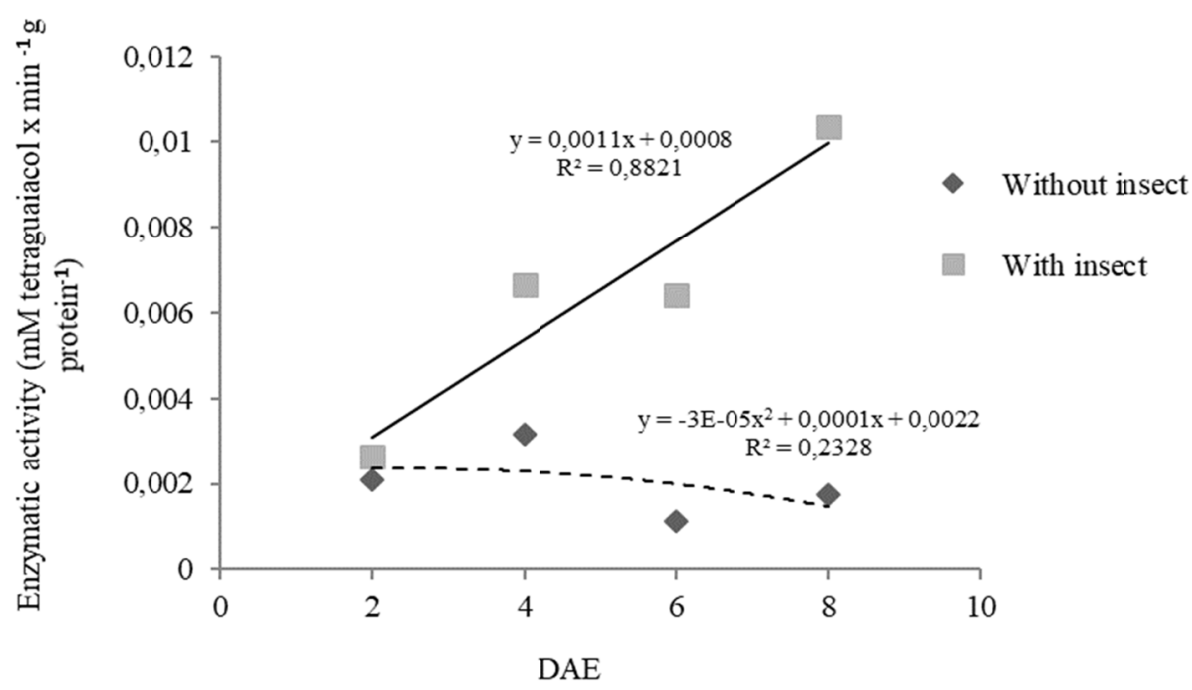

Figure 1. Peroxidase activity versus the plant seedling age separated according to the presence and absence of stink bug Diceraeus melacanthus on different days after emergence (DAE)

Although it has been proposed in our studies to determine the response of corn plants to the presence of $D$. melacanthus and the relationship with the activity of catalase, it was observed that this enzyme did not follow the same behavior observed did for enzyme POD, presenting extremely low levels that could not be quantified. That the stress caused during the presence of D. melacanthus did not activate the production of reactive oxygen forms which are commonly catalyzed by the CAT enzyme. 
Table 2. Comparison of the effect of presence and absence of the stink bug Diceraeus melacanthus in relation on variables plant height (HT), root length (RL), dry mass of aerial part (DMAP), dry root mass (RDM) and peroxidase enzyme (POD) at $2^{\text {nd }}, 4^{\text {th }}, 6^{\text {th }}$ and $8^{\text {th }}$ days after emergence of corn plants

\begin{tabular}{|c|c|c|c|c|c|c|c|c|c|c|}
\hline \multirow{3}{*}{ Variables } & \multicolumn{8}{|c|}{ Days After Plant Emergence } & \multirow{2}{*}{\multicolumn{2}{|c|}{ Total Averages }} \\
\hline & \multicolumn{2}{|c|}{$2^{\text {nd }}$} & \multicolumn{2}{|c|}{$4^{\text {th }}$} & \multicolumn{2}{|r|}{$6^{\text {th }}$} & \multicolumn{2}{|r|}{$8^{\text {th }}$} & & \\
\hline & Presence & Absence & Presence & Absence & Presence & Absence & Presence & Absence & Presence & Absence \\
\hline & \multicolumn{10}{|c|}{ 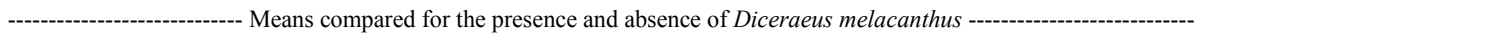 } \\
\hline HT & $3.52 \pm 0.08 \mathrm{~b}$ & $4.66 \pm 0.32 \mathrm{a}$ & $4.44 \pm 0.23 b$ & $5.88 \pm 0.46 \mathrm{a}$ & $5.80 \pm 0.12 \mathrm{a}$ & $6.30 \pm 0.36 \mathrm{a}$ & $4.68 \pm 0.58 \mathrm{~b}$ & $6.40 \pm 0.26 \mathrm{a}$ & $4.61 \pm 0.24 b$ & $5.81 \pm 0.22 \mathrm{a}$ \\
\hline RL & $8.32 \pm 0.73 \mathrm{a}$ & $6.08 \pm 0.98 \mathrm{a}$ & $7.54 \pm 1.15 \mathrm{a}$ & $5.90 \pm 0.47 \mathrm{a}$ & $10.36 \pm 0.93 \mathrm{a}$ & $10.54 \pm 1.14 \mathrm{a}$ & $11.0 \pm 1.72 \mathrm{a}$ & $9.48 \pm 0.75 \mathrm{a}$ & $9.30 \pm 0.64 \mathrm{a}$ & $8.00 \pm 0.61 \mathrm{a}$ \\
\hline DMAP & $0.07 \pm 0.01 \mathrm{a}$ & $0.08 \pm 0.005 \mathrm{a}$ & $0.16 \pm 0.03 \mathrm{a}$ & $0.14 \pm 0.02 \mathrm{a}$ & $0.23 \pm 0.01 \mathrm{a}$ & $0.21 \pm 0.01 \mathrm{a}$ & $0.26 \pm 0.02 \mathrm{a}$ & $0.29 \pm 0.02 \mathrm{a}$ & $0.17 \pm 0.02 \mathrm{a}$ & $0.18 \pm 0.02 \mathrm{a}$ \\
\hline $\mathrm{RDM}$ & $0.05 \pm 0.009 \mathrm{a}$ & $0.05 \pm 0.003 \mathrm{a}$ & $0.06 \pm 0.008 \mathrm{~b}$ & $0.11 \pm 0.02 \mathrm{a}$ & $0.14 \pm 0.008 \mathrm{~b}$ & $0.21 \pm 0.01 \mathrm{a}$ & $0.28 \pm 0.05 \mathrm{a}$ & $0.26 \pm 0.01 \mathrm{a}$ & $0.13 \pm 0.02 \mathrm{a}$ & $0.16 \pm 0.02 \mathrm{a}$ \\
\hline POD & \multicolumn{2}{|c|}{$0.003 \pm 0.0006 \mathrm{a} 0.002 \pm 0.0002 \mathrm{a}$} & \multicolumn{2}{|c|}{$0.007 \pm 0.002 \mathrm{a} 0.003 \pm 0.0004 \mathrm{~b}$} & \multicolumn{2}{|c|}{$0.006 \pm 0.001 \mathrm{a} 0.001 \pm 0.0003 \mathrm{~b}$} & \multicolumn{4}{|c|}{$0.010 \pm 0.001 \mathrm{a} 0.002 \pm 0.0004 \mathrm{~b} 0.006 \pm 0.0008 \mathrm{a} 0.002 \pm 0.0002 \mathrm{~b}$} \\
\hline
\end{tabular}

Note. The same letters in a line indicate no statistical differences between by Tukey's test at 5\% probability.

\section{Discussion}

Herbivorous insects impact on plants, mainly in crops of economic interest. It is known that insect pests can negatively influence the development of cultivated plants. According to the results obtained in this research, the infestation with the stink bug D. melacanthus influenced the development of corn seedlings, and induced the production of defensive $\mathrm{O}_{3}$ molecules by plants, which is demonstrated by the presence of catalyst enzymes.

The reduction in plant height can be considered as reflection of the injury caused by stink bugs. In the present study, it was observed that the green-belly stink bug caused damage to corn plants, resulting in a decrease in plant growth, in particular those plants which were kept with the stink bugs for a longer time (Table 2).

The direct damage caused by sucking insects, as observed for the green-belly stink bug in corn plants, are not notice inicitly, because they are related to internal changes in plant tissues, as compared to the damage caused by chewing insects. Even so, stink bugs can cause direct damage characterized by the suction of cellular content and release of toxic compounds during salivation, which can cause physiological changes in the plant (Lucini, 2017).

The feeding process of $D$. melacanthus was studied by Lucini and Panizzi (2016), who demonstrated that this pest had two distinct feeding characteristics, both direct feeding of xylem-carrying vessels and by inoculation of salivary enzymes and cell disruption. The saliva of these insects has toxic enzymes that lead to deformation and death of plant tissues, one of the possible causes of the reduction in plant height, as reported by Rosa-Gomes et al. (2011).

Corn plants infested by the stink bug D. melacanthus, between phenological stages V1 and V3 show significant damage when compared to older plants (Fernandes et al., 2020). Taking into acount our results, it appears that seedlings at $2^{\text {nd }}$ DAE, phenological stage V1, which were infested by the stink bug D. melacanthus showed a reduction in height of approximately $23 \%$ when compared to plants that were not fed on by the bug. These results prove that the management of $D$. melacanthus is necessary right after the emergence of the plants, or even preventively, through seed treatment.

Stink bugs' presence influence on plant height was also found by Panizzi et al. (2016). According to the data of this study, the infestations of D. furcatus at the initial development stage of the wheat crop reduced the height of the plants. Likewise, Crosariol Netto et al. (2015) obtained results that indicated a reduction in the height of corn plants subjected to D. melacanthus feeding. The same authors also observed that the decrease was more striking in conventional corn hybrids, as compared to transgenic hybrids.

The presence of $D$. melacanthus did not lead to change in the mean values of the root length and DMAP of the corn plant, it was noted that the observed values did not vary from those obtained for plants kept isolated and without the injury caused by the pest (Table 2). Similar results were obtained by Roza-Gomes et al. (2011) who also found no significant difference in the DMAP for plants infested with D. melacanthus. The non-significant effect of the stink bug's presence on the length of the root system may be related to the initial root length of the corn seedlings. In this case the seminal roots evaluated during the experiment tend to have a slower growth immediately after emergence of the corn seedling (Magalhães et al., 2002), thus, the plants of the present experiment, which were evaluated until the eighth day after emergence, did not show any change from the the insects, in these variables.

However, the results of a slower increase of root mass obtained in this study could indicate that there was a negative effect of the photoassimilate transport from the aerial part to the root. The slower increse of root mass 
could have occurred due to the imbalance between the photosynthetic production and consequent reduction in the translocation of nutrients to the root system. This process was determined by Souza and Barbosa (2015), who noticed that plants in a stressful situation tended to be less efficient photosynthetically, due to the high concentration of electrons inside the cells that combined with oxygen form the ROS.

The damage caused by the stink bug, D. melacanthus, manifested in the corn plants and generated oxidative stress and a concomitant increase in the concentration of ROS, verified by the action of the enzyme POD (Table 2).

The activity of the POD enzyme was altered by the presence of the bug, and from the data obtained in this study it could be stated that the activity of POD in healthy plants remained unchanged during the evaluation period (Table 2 and Figure 1).

The changes in the levels of reactive oxigens are the first responses of plants in relation to insect herbivory and beginning of plant's defense system, folowing ativation of antioxidant enzymes activity (Bi \& Felton, 1995). These oxidative molecules can be harmful to plants when produced for long periods and in great intensity, as they are responsible for the peroxidation of membrane lipids and degradation of small molecules such as proteins and DNA (Huang et al., 2019). In addition, they negatively affect herbivorous insects by causing oxidative damage to the intestinal cells and reducing the absorption of the ingested nutrients (Bi \& Felton, 1995).

Several studies have shown the degree of oxidative stress in plants after infestation by phytophagous insects (Ni et al., 2001; Taggar et al., 2012; Kaur et al., 2014). This was determined by the analysis of the antioxidant enzymes. Our results showed that in the longest period of coexistence of the pest and plant, $8^{\text {th }}$ DAE, the plants infested with the stink bug showed that the expression of the POD enzyme was five times higher than plants without the bug. Similar results were obtained by Ni et al. (2001), these authors observed that feeding the aphid Diuraphis noxia (Mordw.) (Hemiptera: Aphididae) increased the activity of the POD enzyme in plants of wheat 'Halt' (Triticum aestivum L., Poaceae) and barley 'Morex' (Hordeum vulgare L., Poaceae). When compared to the control, the increase in POD activity was nine times higher in barley and three times in wheat, nine days after the initial infestation by the pest.

The quantification of antioxidant enzymes can be a way of measuring the degree of resistance of plants to insects, as genotypes that already show indiced resistance to attack by the pest may present a greater activity of antioxidant enzymes (Bi \& Felton, 1995; Heng-Moss et al., 2004). Results by Kaur et al. (2014) indicated that after infestation of the Helicoverpa armigera (Hubner) (Lepidoptera: Noctuideae) a caterpillar, in pigeon pea genotypes (Cajanus cajan L. Millsp., Fabaceae) the activity of the POD enzyme was increased, showing higher values in resistant genotypes.

The increase in POD enzyme activity was also reported by Taggar et al. (2012) in black grass genotypes (Vigna mungo L. Hepper, Fabaceae) subjected to stress conditions by the feeding whitefly, Bemisia tabaci Gennadius (Hemiptera: Aleyrodidae). Moreover, the enzyme activity was even higher in the resistant genotypes, the high enzyme activity negatively influenced the development of the pest, and genotypes with high POD activity had fewer nymphs and whitefly adults (Taggar et al., 2012). Our results also demonstrate similar responses of corn seedlings in relation to infestation by $D$. melacanthus, increasing the activity of the enzyme POD. These findings pave the way for further studies on the negative effect of plant responses on the development of insect pests.

Through the quantification of the POD enzyme it was possible to observe that the biotic stress caused by the stink bug increased with increasing time of infestation with the stink bugs, i.e., the longer the insect fed on the plants, the greater the expression of the POD enzyme. However, this effect was not noticed in the non-infested control plants, in which the activity of the enzyme was practically constant over time, proving the effect of the stink bug in the expression of the POD enzyme. Therefore, the earlier the stink bug D. melacanthus is controlled in the field, the lower the possible expenses of the plant in the production of defensive compounds.

Both POD and several other antioxidant enzymes can be used to identify the stress suffered by the plant through insect injury, as demonstrated by Hanaka et al. (2018). The authors observed an increase in the expression of the enzymes superoxide dismutase, catalase, ascorbate peroxidase, and guaiacol peroxidase in corn plants, after a biotic stress caused by the infestation of the stink bug, Trigonotylus caelestialium (Kirkaldy) (Hemiptera: Miridae). Plants were attacked by the stink bugs had higher levels of antioxidant enzymes in their leaves and roots, when compared to plants not occupied with the stink bugs.

The activity and concentration of the CAT enzyme can vary according to the stress suffered by the plant (Vasconcelos et al., 2009). The CAT enzyme is very efficient in removing high levels of $\mathrm{H}_{2} \mathrm{O}_{2}$, but not so suitable for low concentrations of this molecule (Nicholls et al., 2000). This relationship may explain the 
non-activity of this enzyme observed in the present study, probably due to the low level of production of $\mathrm{H}_{2} \mathrm{O}_{2}$ molecules, even though the plant had suffered stress; in this case, the POD enzyme was efficient in degrading the $\mathrm{H}_{2} \mathrm{O}_{2}$ produced.

The greater the activity of antioxidant enzymes, the greater the concentration of ROS in the plant, that is, the plant's stress is greater due to the attack of the pest or another factor that stimulates stress. The study of intracellular ROS concentration and the activity of POD and other antioxidant enzymes can be a tool to quantify the biotic stress of plants, due are influenced by herbivory caused by insects. The Hemiptera being the largest group of insects studied, due to the difficulty to observe and measure the damage caused by these pests (Nascimento \& Barrigossi, 2014).

\section{Conclusion}

The injury caused by $D$. melacanthus, in addition to affecting the development of corn seedlings, as reduced plant height, they also interfered with the accumulation of RDM and caused biotic stress to plants, which could be quantified by the POD enzyme.

\section{Acknowledgements}

This study was financed in part by the Coordenação de Aperfeiçoamento de Pessoal de Nível Superior-Brasil (CAPES)-Finance Code 001, for granting a master scholarship to the first author.

\section{References}

Aebi, H. (1984). Catalase in vitro. Methods Enzymol, 105, 121-126. https://doi.org/10.1016/s0076-6879(84) 05016-3

Bi, J. L., \& Felton, G. W. (1995). Foliar oxidative stress and insect herbivory: Primary compounds, secondary metabolites, and reactive oxygen species as componentes of induced resistance. Journal of Chemical Ecology, 21(10), 1511-1530. https://doi.org/10.1007/BF02035149

Bridi, M., Kawakami, J., \& Hirose, E. (2016). Danos do percevejo Dichelops melacanthus (Dallas, 1851) (Heteroptera: Pentatomidae) na cultura do milho. Magistra, 28(3), 301-307.

Chiesa, A. C. M., Sismeiro, M. N. S., Pasini, A., \& Roggia, S. (2016). Tratamento de sementes para manejo do percevejo-barriga-verde na cultura de soja e milho em sucessão. Pesquisa Agropecuária Brasileira, 51(4), 301-308. https://doi.org/10.1590/S0100-204X2016000400002

Chocorosqui, V. R. (2001). Bioecologia de Dichelops (Diceraeus) melacanthus (Dallas, 1851) (Heteroptera: Pentatomidae), danos e controle em soja, milho e trigo no norte do Paraná (Unpublished doctoral dissertation, Universidade Federal do Paraná, Curitiba, Brasil).

Chocorosqui, V. R., \& Panizzi, A. R. (2002). Temperature influence on the nymphal biology of Dichelops melacanthus (Dallas, 1851) (Heteroptera: Pentatomidae). Semina: Ciências Agrárias, 23(2), 217-220. https://doi.org/10.5433/1679-0359.2002v23n2p217

Chocorosqui, V. R., \& Panizzi, A. R. (2004). Impact of cultivation systems on Dichelops melacanthus (Dallas) (Heteroptera: Pentatomidae) population and damage and its chemical control on wheat. Neotropical Entomology, 33(4), 487-492. https://doi.org/10.1590/S1519-566X2004000400014

Coelho, H. A. (2013). Diferentes condições de estresse hídrico no desenvolvimento de milho transgênico e convencional (Unpublished doctoral dissertation, Universidade Estadual "Júlio de Mesquita Filho", Botucatu, Brasil).

Copatti, J. F., \& Oliveira, N. C. (2011). Danos iniciais causados pelos percevejos Dichelops melacanthus e Euschistos heros (Hemiptera: Pentatomidae) em plantas de milho. Revista Campo Digital, 6(1), 1-8.

Crosariol Netto, J., Michelotto, M. D., Grigolli, J. F. J., Galli, J. A., Pirotta, M. Z., \& Busoli, A. C. (2015). Damage caused by Dichelops melacanthus (Heteroptera: Pentatomidae) in conventional and transgenic corn hybrids. Bioscience Journal, 31(4), 1092-1101. https://doi.org/10.14393/BJ-v31n4a2015-26323

Cruz, I., Viana, P. A., \& Waquil, J. M. (2002). Cultivo de milho: Pragas da fase vegetativa e reprodutiva. Embrapa Milho e Sorgo, Sete Lagoas.

Fernandes, P. H. R., Ávila, C. J., Silva, I. F., \& Zulin, D. (2020). Damage by green-bellystink bug to corn. Pesquisa Agropecuária Brasileira, 55, 1-6. https://doi.org/10.1590/s1678-3921.pab2020.v55.01131

Hanaka, A., Lechowski, L., Mroczek-Zdyrska, M., \& Strubínska, J. (2018). Oxidative enzymes activity during abiotic and biotic stresses in Zea mays leaves and roots exposed to $\mathrm{Cu}$, methyl jasmonate and Trigonotylus 
caelestialium. Physiology and Molecular Biology of Plants, 24(1), 1-5. https://doi.org/10.1007/s12298017-0479-y

Heng-Moss, T., Sarath, G., Baxendale, F., Novak, D., Bose, S., Ni, X., \& Quisenberry, S. (2004). Characterization of oxidative enzyme changes in buffalograsses challenged by Blissus occiduus. Journal of Economic Entomology, 97(3), 1086-1095. https://doi.org/10.1093/jee/97.3.1086

Huang, H., Ullah, F., Zhou, D. X., Yi, M., \& Zhao, Y. (2019). Mechanisms of ROS regulation of plant developmente and stress responses. Frontiers in Plant Science, 10, 1-10. https://doi.org/10.3389/ fpls.2019.00800

Inzé, D., \& Montagu, M. V. (1995). Oxidative stress in plants. Current Biology, 6(2), 153-158. https://doi.org/10.1016/0958-1669(95)80024-7

Kaur, R., Gupta, A. K., \& Taggar, G. K. (2014). Role of catalase $\mathrm{H}_{2} \mathrm{O}_{2}$ and phenolics in resistance of pigeonpea towards Helicoverpa armigera (Hubner). Acta Physiologiae Plantarum, 36, 1513-1527. https://doi.org/ 10.1007/s11738-014-1528-6

Lucini, T. (2017). Monitoramento eletrônico das atividades alimentares de percevejos pentatomídeos em diferentes plantas hospedeiras por meio da técnica de EPG (Electrical Penetration graph) (Unpublished doctoral dissertation, Universidade Federal do Paraná, Curitiba, Brasil).

Lucini, T., \& Panizzi, A. R. (2016). Feeding behavior of the stinck bug Dichelops melacanthus (Heteroptera: Pentatomidae) on maize seedlings: Na EPG analysis at multiple input impedances and histology correlation. Annals of the Entomological Society of America, 110(2), 160-171. https://doi.org/10.1093/aesa/saw070

Lucini, T., \& Panizzi, A. R. (2018). Eletropenetrografia (EPG): uma ferramenta inovadora que revela percevejos (Pentatomidae) que se alimentam de plantas. Neotropical Entomology, 47, 6-18. https://doi.org/10.1007/ s13744-017-0574-3

Maffei, M. E., Mithöfer, A., \& Boland, W. (2007). Insects feeding on plants: Rapid signals and responses preceding the induction of phytochemical release. Phytochemistry, 68(22-24), 2946-2959. https://doi.org/ 10.1016/j.phytochem.2007.07.016

Nascimento, J. B., \& Barrigossi, J. A. F. (2014). O papel das enzimas antioxidantes na defesa das plantas contra insetos herbívoros e fitopatógenos. Agrarian Academy, 1(1), 234-250. https://doi.org/10.18677/ Agrarian_Academy_2014_021

Nicholls, P., Fita, I., \& Loewen, P. C. (2000). Enzymology and structure of catalases. Advances in Inorganic Chemistry, 51(2), 51-106. https://doi.org/10.1016/S0898-8838(00)51001-0

Ni, X., Quisenberry, S. S., Henh-Moss, T., Markwell, J., Sarath, G., Klucas, R., \& Baxendale, F. (2001). Oxidative responses of resistant and susceptible cereal leaves to symptomatic and nonsymptomatic cereal aphid (Hemiptera: Aphididae) feeding. Journal of Economic Entomology, 94(3), 743-751. https://doi.org/ 10.1603/0022-0493-94.3.743

Panizzi, A. R., Agostinetto, A., Lucini, T., \& Pereira, P. R. V. S. (2016). Effect of green-belly stink bug, Dichelops furcatus (F.) on wheat yield and development. Crop Protection, 79(2), 20-25. https://doi.org/ 10.1016/j.cropro.2015.10.006

Panizzi, A. R., \& Chocorosqui, V. R. (2000). Os percevejos inimigos. A Granja, 616, 40-42.

Panizzi, A. R., \& Lucini, T. (2019). Body position of the stink bug Dichelops melacanthus (Dallas) during feeding from stems of maize seedlings. Brazilian Journal of Biology, 79(2), 304-310. https://doi.org/ $10.1590 / 1519-6984.18250$

Pütter, J. (1974). Peroxidases. In H. V. Bergmeryer (Ed.), Methods of enzymatic analysis (p. 685). Academic Press Inc, New York, United States. https://doi.org/10.1016/B978-0-12-091302-2.50033-5

Rodrigues, R. B. (2011). Danos do percevejo-barriga-verde Dichelops melacanthus (Dallas, 1851) (Hemiptera: Pentatomidae) na cultura do milho (Unpublished doctoral dissertation, Universidade Federal de Santa Maria, Santa Maria, Brasil).

Roza-Gomes, M. F., Salvadori, J. R., Pereira, P. R. V. S., \& Panizzi, A. R. (2011). Injúrias de quatro espécies de percevejos pentatomídeos em plântulas de milho. Ciência Rural, 41(7), 1115-1119. https://doi.org/ $10.1590 / \mathrm{S} 0103-84782011005000081$ 
Sas Institute. (2013). Sas/Stat User Software: Changes and 14 Enhancements through Release (Versão 9.4). Estados Unidos, Cary.

Soares, A. M. S., \& Machado, O. L. T. (2007). Defesa de plantas: sinalização química e espécies reativas de oxigênio. Revista Trópica, 1(1), 9-19.

Souza, G. M., \& Barbosa, A. M. (2015). Fatores de estresse no milho são diversos e exigem monitoramento constante. Revista Visão Agrícola, 13, 30-34.

Taggar, G. K., Gill, R. S., Gupta, A. K., \& Sandhu, J. S. (2012). Fluctuations in peroxidase and catalase activities of resistence and susceptible black gram (Vigna mungo (L.) Hepper) genotypes elicited by Bemisia tabaci (Gennadius) feeding. Plant Signaling \& Behavior, 7(10), 1321-1329. https://doi.org/10.4161/psb.21435

Torres, A. B. A., Oliveira, N. C., Oliveira Neto, A. M., \& Guerreiro, J. C. (2013). Injúrias causadas pelo ataque dos percevejos marrom e barriga verde durante o desenvolvimento inicial do milho. Journal of Agronomic Sciences, 2(2), 169-177.

Vasconcelos, A. C. F., Zhang, X., Ervin, E. H., \& Kiehl, J. C. (2009). Enzymatic antioxidant responses to biostimulants in maize and soybbean subjected to drought. Scientia Agricola, 66(3), 395-402. https://doi.org/10.1590/S0103-90162009000300015

War, A. R., Paulraj, M. G., Ahmad, T., Buhroo, A. A., Ignacimuthu, S., \& Sharma, H. C. (2012). Mechanism of plant defense against insect herbivores. Plant Signaling \& Behavior, 7(10), 1306-1320. https://doi.org/ $10.4161 /$ psb. 21663

\section{Copyrights}

Copyright for this article is retained by the author(s), with first publication rights granted to the journal.

This is an open-access article distributed under the terms and conditions of the Creative Commons Attribution license (http://creativecommons.org/licenses/by/4.0/). 